\title{
Psychological Causes of Residential and Day Scholar School Dropout
}

\author{
Dr. Deepak Pandey ${ }^{1 *}$
}

\section{ABSTRACT}

The present study explored the difference between some psychological causes of residential and day scholar school dropout. A total number of 200 boy's school dropout students in government schools of Chhattisgarh state were selected randomly, which comprised of 100 residential and 100 day scholar elementary school students. Dropout was measured of self developed questionnaire. Dimension wise Guttman split half reliability, item wise factor loading, inter factors correlation shows good psychometric properties about the questionnaire. Result of Fratio showed that residential \& day scholar school dropout student differs with respect to the school environment, child-parent relationship, child-teacher relationship, interest of education significant positively.

Keywords: Residential \& day scholar school dropout, Quality of school life, Peer factors, School environment, Child-parent relationship, Child- teacher relationship, Interest of education.

Dropout means leaving a school or group for practical reasons, necessities, or disenchantment with the system from which the individual in question leaves (Wikipedia, 2013). Student discipline and absenteeism in school are strong predictors of school dropout, dropping out is influence of social and academic experience of students (Bachman et al., 1971; Carbonaro, 1998; Ekstrom et al., 1986; Goldschmidt \& Wang, 1999; Grant \& Hallman, 2006; Rumberger, 1995; Rumberger \& Larson, 1998; Swanson \& Schneider, 1999; Wehlage \& Rutter, 1986). Parents monitor and regulate student activities, provide emotional support, encourage independent decision-making and generally involved in their schooling are less likely to drop out of school (Aston \& Melanahan 1991; Rumberger, 1995; Ainsworth et al., 2005). Early academic achievement and engagement like regular attendance, misbehavior in elementary and middle school, predicted withdrawal from high school student engagement include student participation identification with school or social bonding, academic performance (Finn, 1993; Maehr \& Midgley, 1996). Large school had higher dropout rates than small schools, school size and school climate are significant predictors of school dropout (Merritt 1983; Pitterman \& Haughwoughwont, 1987). Small school size is an important variable that facilitates a healthy

\footnotetext{
${ }^{1}$ NMHS Member, Department of Psychiatry, All India Institute of Medical Sciences Raipur, Chhattisgarh, India *Responding Author (C) 2016 I D Pandey; licensee IJIP. This is an Open Access Research distributed under the terms of the Creative Commons Attribution License (http://creativecommons.org/licenses/by/2.0), which permits unrestricted use, distribution, and reproduction in any Medium, provided the original work is properly cited.
} 
environment for student and teachers' engagement (Bryk \& Thion, 1989). School facilities and especially punishment school factors have been shown to contribute to the school dropout. Drop out of schools comes from a variety of sources such as within students' families. School and communities (and peer) on the child behavior, that the socioeconomic status, most commonly measured by parental education and income is a powerful predictor of school achievement and dropout behavior (Ekstrom et al., 1986; McMeal, 1999; Rumberger, 1995; Rumberger \& Larson, 1998; Pong \& Ju 2000). High levels of schools satisfaction are positively associated with acceptance of educational values, commitment to school. Family background, personal problem and school related factor are significant predictors of school dropout. Child drop out of schools comes from a variety of sources such as within students' families. Various aspects of teachinglearning are also linked to dropping out the poor teaching, learning transaction leading to low motivation, low comprehension and finally dropping out one instance (Chaudhary et al., 2005). Quality of school life is predominantly associated with personality factors, in particular school self-esteem, relation to the trait character of quality of school life and educational implication of the model (Karatzias, Power, Flemming, Lennon \& Susanson, 2002).

\section{OBJECTIVE}

Following objectives included in this present research work:

1. To study differences between some psychological causes of residential and day scholar school dropout.

\section{Hypothesis}

Following hypothesis included in present research work:

1. Residential school dropout students will differ significantly from day scholar school dropout student with respect to quality of school life.

2. Residential school dropout students will differ significantly from day scholar school dropout student with respect to school environment.

3. Residential school dropout students will differ significantly from day scholar school dropout student with respect to child- parent relationship.

4. Residential school dropout students will differ significantly from day scholar school dropout student with respect to child- teacher relationship.

5. Residential school dropout students will differ significantly from day scholar school dropout student with respect to peer factor.

6. Residential school dropout students will differ significantly from day scholar school dropout student with respect to interest of education.

\section{METHOD}

\section{Research design}

In the present research work survey research design was used. 


\section{Sample \& Inclusion criteria}

Sampling has done by random selection as shown the below table:

\begin{tabular}{|l|l|l|l|l|}
\hline \multirow{2}{*}{$\begin{array}{l}\text { Age } \\
\text { Group }\end{array}$} & Target subject & $\begin{array}{l}\text { Target } \\
\text { Area }\end{array}$ & $\begin{array}{l}\text { Tesidential } \\
\text { School }\end{array}$ & Day Scholar \\
\cline { 3 - 5 } $\begin{array}{l}\text { 6-14 year } \\
\text { (boys) }\end{array}$ & $\begin{array}{l}\text { School dropout } \\
\text { students }\end{array}$ & $\begin{array}{l}\text { Government } \\
\text { Schools of } \\
\text { Chhattisgarh }\end{array}$ & 100 students & 100 students \\
\hline
\end{tabular}

\section{Tools}

Self developed psychological scale was used. Following dimension wise psychometric properties in this test:-

Table 1: Dimension, No. of items, Response category \& scoring pattern, Guttman split half reliability

Table 2: Maximum likelihood estimates of the oblique factor loadings for the 23-item wise test

Table 3: Eigen values, percentage of explained variance, inter-factor correlations and Factortotal correlations for the test

Predictive validity: - Re-administered this test to 100 dropout subject.

Table 4: Test-retest correlation (4-week interval)

\section{RESULT \& DISCUSSION}

With a view to obtain evidence for the hypotheses formulated, it was decided to employ the ANOVA technique. Each hypothesis will now be considered separately to see whether or not, it is supported in terms of the data obtained and analyzed.

Table 5: Summary of F-ratio table

The data in the table -5 indicate that the quality of school life main effect F- ratio is 1.28 which is not significant. It reveals that Residential \& day scholar school dropout students does not differ with quality of school life significantly (Chaudhary et al., 2005). Researchers are also reporting that quality of school life significantly associated with school dropout (Karatzias, Power, Flemming, Lennon \& Susanson, 2002). School environment main effect F - ratio is 12.85 which are significant. It reveals that Residential \& day scholar school dropout students differs with school environment significantly (Merritt, 1983; Pitterman \& Haughwoughwont, 1987; Bryk \& Thion, 1989). Moreover child-parent relationship main effect F- ratio is 10.15 which are significant. It reveals that Residential \& day scholar (Aston \& Melanahan, 1991; Rumberger, 1995; Ainsworth et al., 2005). Furthermore child-teacher relationship main effect F- ratio is 8.52 which are significant. It reveals that Residential \& day scholar school dropout students is differ with child-teacher relationship significantly (Bochman et al., 1971; Carbonaro, 1998; Ekstrom et al., 1986; Goldschmidt \& Wang, 1999; Rumberger, 1995; Rumberger \& Larson, 1998; Swanson \& Schneider, 1999; Wehlage \& Rutter, 1986; Grant \& Hallman, 2006). Likely the peer factor 
main effect F- ratio is 0.85 which are not significant. It reveals that Residential \& day scholar school dropout students does not differ with peer factor significantly (Ekstrom et al., 1986; McMeal, 1999; Rumberger; 1995; Rumberger \& Larson 1998; Pong \& Ju, 2000). Furthermore the interest of education main effect F- ratio is 12.52 which are significant. It reveals that Residential \& day scholar school dropout students differs with interest of education significantly (Finn, 1993; Maehr \& Midgely, 1996).

\section{CONCLUSION}

It may be concluded on the basis of the above statistical findings and supporting studies, second, third, fourth and sixth hypothesis accepted, and the basis of above finding it is clear to say that residential \& day scholar school dropout students is significantly positive difference with school environment, child-parent relationship, child- teacher relationship and interest of education. Furthermore first, and fifth hypothesis is not accepted. On the basis of above findings residential \& day scholar school dropout students is not found significantly differences with quality of school life and peer factors dimensions.

\section{REFERENCES}

Ainsworth, M., Beegle, K. \& Kola, G. (2005). The impact of adult mortality and parental deaths on primary schooling in north- western Tanzania. The journal of developmental studies, 41 (3), 412-439.

Astone, N.M. \& Mclanahan, S.S. (1991). Family structure, parental practices and high school completion. American sociological review, 56, 309-320.

Bachman, J.G., Green, S. \& Wirtanen, I.D. (1971). Youth in transition, droppimg out: Problem or symptoms? Ann Arbor, MI: Institute for Social Research,University of Michigen.

Bryk \& Thum (1989). The effect of high school organization on dropping out:An exploratory investigation. American educational research journal 26 (3) 353-383.

Carbonaro, W.J. (1998). A littile help from my friend's parents: Intergeneration closure and census of india, 1991-2001: Final population totals, series -1.

Chaudhury, N., Hammer, J., Kremer, M., Murlidharan, K. \& Halsey Rogers, F. (2005). Missing in action: Teacher and health worker absence in developing countries available from http://www.economics.harvard.edu/faculty/kremer/files/Missingin Action.pdf

Ekstrom, R.B., Geortz, M.E., Oallack, J.M. \& Rock, D.A. (1986). Who drop out of high school and why? Finding from a national survey. Teacher College Record. 87, 357-373.

Finn, J.D. (1993). School engagement \& student at risk. Washington, DC: National Center for Education Statistics.

Goldscmidt, P. \& Wang, J. (2006). When can school affect dropout behavior?. American educational research journal, 36, 715-738.

Grant, M. \& Hallman, K. (2006). Pregnancy related school dropout and school performance in south Africa. Policy research divine, working paper No 212. New York: Population Council. 
Karatzias, A., Power, K.G., Flemming, J., Lennan, F., \& Swanson, V. (2002). The role of Demographics, Personality Variables and School stress on predicting school satisfaction/dissatisfaction. Educational Psychology: An International Journal of Experimental Education Psychology. 22 (1). 33-50.

Maehr, M.L. \& Midgley, C. (1996). Transforming school culture. Boulder, CO: Westview Press. McNeal, R.B. (1999). Parnt Involvment as Social Capital: Differential Effectiveness on Science Achievment, Truancy, and Dropping out. Social Forces, 78, 117-144.

Merrit, R. (1983). The effect of enrollment and school organisation on the dropout rate. Phi Delta Kappan. 68 (3). 224.

Pittman, R.B. \& Hanghwout (1987). Influence of high schools size on dropout rate. Educational Evaluation and Policy Analysis. 9 (4). 337-343.

Pong, S.L. \& Ju, D.B. (2000). Effects of change in family structure and income on dropping out of middle and high school. Journal of Family Issues, 21 (2), 147-169.

Rumberger, R.W. \& Larson, K.A. (1998). Student Mobility and the increased risk of high school dropout. American Journal of Education, 107, 1-35.

Rumberger, R.W. (1995). Dropping out of middle school: A multilevel analysis of students and schools. American Educational Research Journal, 32, 583-625.

Swanson, C.B. \& Schneider, B. (1999). Students on the move: Residential and educational mobility in america's schools. Sociology of Education, 72, 54-67.

Wehlage \& Rutter (1986). Dropping out: How much do schools contribute to the problem? In Natriello. G (ed.) School dropouts: pattern and policies, pp 70-88, New York.

Wikipedia (2013). The meaning of drop-out students elementary.www.csos.jhu.education.

Table 1, Dimension, No. of items, Response category \& scoring pattern, Guttman split half reliability

\begin{tabular}{|c|c|c|c|}
\hline Dimension & $\begin{array}{l}\text { Total No. of } \\
\text { items }\end{array}$ & $\begin{array}{l}\text { Response category } \\
\text { \& scoring pattern }\end{array}$ & $\begin{array}{l}\text { Guttman split half } \\
\text { reliability }\end{array}$ \\
\hline Quality of school life & 3 & \multirow{6}{*}{$\begin{array}{l}\text { Yes }=1 \\
\text { No }=0 \\
\text { Highest score }=23 \\
\text { Lowest Score }=0\end{array}$} & .75 \\
\hline School environment & 4 & & .65 \\
\hline Child-parent relationship & 3 & & .85 \\
\hline Child-teacher relationship & 4 & & .86 \\
\hline Peer factor & 5 & & .75 \\
\hline Interest of education & 4 & & .69 \\
\hline Total & 23 & & .75 \\
\hline
\end{tabular}


Psychological Causes of Residential and Day Scholar School Dropout

Table 2, Maximum likelihood estimates of the oblique factor loadings for the 23-item wise test

\begin{tabular}{|c|c|c|c|c|c|c|}
\hline \multirow[b]{2}{*}{ Item } & \multicolumn{6}{|c|}{ Factor loadings } \\
\hline & $\begin{array}{l}\text { Quality of } \\
\text { school life }\end{array}$ & $\begin{array}{l}\text { School } \\
\text { environment }\end{array}$ & $\begin{array}{l}\text { Child-parent } \\
\text { relationship }\end{array}$ & $\begin{array}{l}\text { Child-teacher } \\
\text { relationship }\end{array}$ & $\begin{array}{l}\text { Peer } \\
\text { factor }\end{array}$ & $\begin{array}{l}\text { Interest of } \\
\text { education }\end{array}$ \\
\hline Q1 & .55 & - & - & - & - & - \\
\hline Q2 & - & .59 & - & - & - & - \\
\hline Q3 & .57 & - & - & - & - & - \\
\hline Q4 & - & - & .65 & - & - & - \\
\hline Q5 & - & .89 & - & - & - & - \\
\hline Q6 & - & - & - & .57 & - & - \\
\hline Q7 & .66 & - & - & - & - & - \\
\hline Q8 & - & .75 & - & - & - & - \\
\hline Q9 & - & - & - & .89 & - & - \\
\hline Q10 & - & - & .49 & - & - & - \\
\hline Q11 & - & .65 & - & - & - & - \\
\hline Q12 & - & - & .85 & - & - & - \\
\hline Q13 & - & - & - & - & .58 & - \\
\hline Q14 & - & - & - & - & - & .89 \\
\hline Q15 & - & - & - & .82 & - & - \\
\hline Q16 & - & - & - & - & .78 & - \\
\hline Q17 & - & - & - & - & - & .79 \\
\hline Q18 & - & - & - & - & .69 & - \\
\hline Q19 & - & - & - & - & - & .75 \\
\hline Q20 & - & - & - & - & .59 & - \\
\hline Q21 & - & - & - & .87 & - & - \\
\hline Q22 & - & - & - & - & - & .64 \\
\hline Q23 & - & - & - & - & .78 & \\
\hline \multicolumn{2}{|l|}{ KMO } & \multicolumn{2}{|c|}{ Bartlett's sphericity } & \multicolumn{3}{|l|}{ Determinant } \\
\hline \multicolumn{2}{|l|}{.75} & \multicolumn{2}{|c|}{$\begin{array}{l}\text { Chi square }=2717.34 \\
P<.000\end{array}$} & \multicolumn{3}{|l|}{.06} \\
\hline
\end{tabular}


Table 3, Eigen values, percentage of explained variance, inter-factor correlations and Factor-total correlations for the test

\begin{tabular}{|c|c|c|c|c|c|c|c|c|}
\hline & \multirow[b]{2}{*}{ 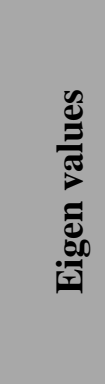 } & \multirow[b]{2}{*}{ 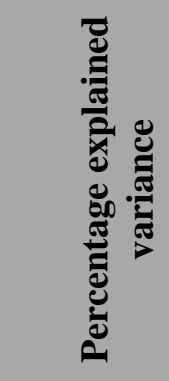 } & \multicolumn{6}{|c|}{ Inter-Factor correlations } \\
\hline & & & 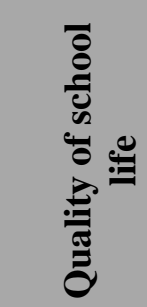 & 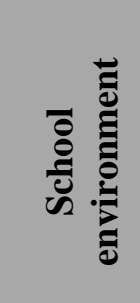 & 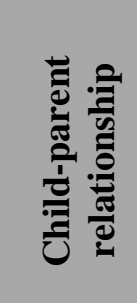 & 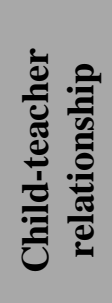 & 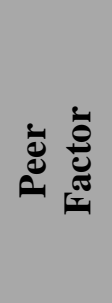 & 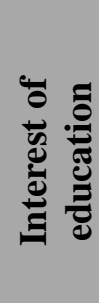 \\
\hline $\begin{array}{l}\text { Quality of } \\
\text { school life }\end{array}$ & 4.10 & 44.02 & .95 & & & & & \\
\hline $\begin{array}{l}\text { School } \\
\text { environment }\end{array}$ & 3.25 & 33.25 & -.85 & .75 & & & & \\
\hline $\begin{array}{l}\text { Child-parent } \\
\text { relationship }\end{array}$ & 2.85 & 21.53 & .32 & .35 & .87 & & & \\
\hline $\begin{array}{l}\text { Child-teacher } \\
\text { relationship }\end{array}$ & 2.19 & 15.23 & .26 & .17 & .35 & .76 & & \\
\hline $\begin{array}{l}\text { Peer } \\
\text { factor }\end{array}$ & 1.85 & 13.13 & .10 & .11 & .15 & -.98 & .65 & \\
\hline $\begin{array}{ll}\begin{array}{l}\text { Interest } \\
\text { education }\end{array} & \text { of }\end{array}$ & 1.02 & 8.66 & -.65 & -.45 & .10 & .12 & .10 & .69 \\
\hline
\end{tabular}

Table 4, Test-retest correlation (4-week interval)

\begin{tabular}{|l|l|l|l|l|l|l|}
\hline Dimension & $\begin{array}{l}\text { Quality of } \\
\text { school life }\end{array}$ & $\begin{array}{l}\text { School } \\
\text { environment }\end{array}$ & $\begin{array}{l}\text { Child-parent } \\
\text { relationship }\end{array}$ & $\begin{array}{l}\text { Child- } \\
\text { teacher } \\
\text { relationship }\end{array}$ & $\begin{array}{l}\text { Peer- } \\
\text { factor }\end{array}$ & $\begin{array}{l}\text { Interest of } \\
\text { education }\end{array}$ \\
\hline $\begin{array}{l}\text { Predictive } \\
\text { validity }\end{array}$ & 0.9 & 0.85 & 0.9 & 0.75 & 0.89 & 0.84 \\
\hline
\end{tabular}

Table 5, Summary of F-ratio table

\begin{tabular}{|l|l|l|l|l|l|l|}
\hline Variable & $\begin{array}{l}\text { Quality } \\
\text { of school } \\
\text { life }\end{array}$ & $\begin{array}{l}\text { School } \\
\text { environment }\end{array}$ & $\begin{array}{l}\text { Child-parent } \\
\text { relationship }\end{array}$ & $\begin{array}{l}\text { Child-teacher } \\
\text { relationship }\end{array}$ & $\begin{array}{l}\text { Peer- } \\
\text { factor }\end{array}$ & $\begin{array}{l}\text { Interest of } \\
\text { education }\end{array}$ \\
\hline $\begin{array}{l}\text { Residential } \\
\text { \& Day } \\
\text { Scholar } \\
\text { School } \\
\text { dropout }\end{array}$ & 1.28 & 12.85 & 10.15 & 8.52 & 0.85 & 12.52 \\
\cline { 2 - 7 } & NS & Sig. & Sig. & Sig. & NS & Sig. \\
\hline
\end{tabular}

How to cite this article: D Pandey (2016), Psychological Causes of Residential and Day Scholar School Dropout, International Journal of Indian Psychology, Volume 3, Issue 3, No. 7, DIP: 18.01.133/20160303, ISBN: 978-1-365-12175-3 